\title{
A Review on in vitro Culture of Aloe vera, Type of Explants and Impact of Growing Media and Growth Regulators
}

\author{
Jugabrata Das $^{1^{*}}$, Sunil Bora ${ }^{2}$, Manosh Das ${ }^{3}$ and Purnima Pathak ${ }^{4}$ \\ ${ }^{1}$ College of Horticulture, Assam Agricultural University, Jorhat, India \\ ${ }^{2}$ Department of Horticulture, Assam Agricultural University, Jorhat, India \\ ${ }^{3}$ Tezpur University, Tezpur, Assam, India \\ ${ }^{4}$ College of Horticulture, Assam Agricultural University, Jorhat, India \\ *Corresponding author
}

\section{A B S T R A C T}

\begin{tabular}{|c|}
\hline Keywords \\
\hline $\begin{array}{l}\text { Tissue culture, } \\
\text { micropropagation, in vitro } \\
\text { shoot induction, } \\
\text { proliferation, rooting, } \\
\text { growing media }\end{array}$ \\
\hline Article Info \\
\hline $\begin{array}{l}\text { Accepted: } \\
25 \text { May } 2018 \\
\text { Available Online: } \\
10 \text { June } 2018\end{array}$ \\
\hline
\end{tabular}

\section{Introduction}

The science and development of plant tissue culture is linked with the discovery of cell followed by propounding of cell theory. In 1839, Schleiden and Schwann proposed that cell is the basic unit of organisms and is capable of autonomy. Each cell has the ability to regenerate into whole plant and this potential of a cell to grow and divide in a selfregularity manner is known as totipotency, a term coined by Steward in 1968. Based on this premise, in 1902, a German physiologist,

\begin{abstract}
Aloe vera is one of the oldest known medicinal plant gifted by nature which is often called as 'Miracle plant' for its versatile properties. It has valuable medicinal benefits and is commercially used in pharmaceuticals, cosmetics and food industries as nutraceuticals. In nature, Aloe vera is vegetatively propagated through suckers or lateral shoots which is a slow, expensive and low income practice. Sexual reproduction by seeds is also inefficient due to the presence of male sterility. Thus regeneration of Aloe vera in nature is too slow and insufficient to meet the industrial demand. Therefore, there is a need to develop a suitable and alternative method of in vitro propagation for rapid plant production of Aloe vera. However, source of explants, size, age, genotype, media composition, culture conditions and exudation of phenolic compound from explants and media discoloration greatly affect shoot regeneration from different genotypes of the same species. The technique of tissue and organ culture is used for rapid multiplication of plants and one of the major applications of tissue culture is micropropagation.
\end{abstract}


versatile tool to explore morphogenesis and to demonstrate totipotency of plant cells. With the passage of time most of these ideas were confirmed experimentally proving his broad vision and foresight. Recent progress in the field of plant cell and tissue culture has made this area of research into one of the most dynamic and promising tools in experimental biology. In vitro cultures are now also being used as tools for the study of various basic problems in plant physiology, plant pathology, cell biology and genetics in addition to agriculture, forestry and horticulture which subsequently have turned the "dreams" of Haberlandt, White and Gautheret into realities.

The discovery and documentation of the role of plant hormones like auxins, (Went and Thimann, 1937) and cytokinins (Skoog and Miller, 1957) in plant tissue culture served as major thrust for the advancements in this field of science. In addition to this discoveries, the invention of the culture medium by Murashige and Skoog (1962), laid the perfect foundation for a wide avenue for research on in vitro proliferation and multiplication of different plant species. The pioneering experiments of White (1934, 1939), Gautheret (1939), Morel and Martin (1952), Skoog and Miller (1957), Steward et al., (1958), Morel (1960), Reinert (1967), Murashige et al., (1972), Carlson et al., (1972), Murashige (1974, 1978), Navarro et al., (1975), Hu and Wang (1983) and Litz (1984, 1985) are often cited as the landmarks in the developmental phases of plant tissue culture.

According to Murashige (1974), there are three possible methods available for micropropagation.

Enhanced release of axillary buds.

Production of advantageous shoots through organogenesis.
Somatic embryogenesis.

In shoot tip and axillary bud cultures, genetic fidelity is maintained to a large extent. In vitro somatic embryogenesis is limited to a few species but still act as the most rapid method for plant regeneration.

Currently, in vitro clonal propagation strategies have been developed for a number of economically important plant species. More and more species are becoming amenable for subjects have been developed by Murashige (1974, 1975), Hu and Wang (1983), Styler and Chin (1983), Sharp et al., (1984) and Litz (1985).

Considering the importance of Aloe vera \& its propagation by tissue culture, this review work is presented describing the various essential components and methods in the following subheads.

\section{Propagation by tissue culture}

Micropropagation is the most commercially exploited area of plant tissue culture, which is a powerful tool for large scale production of planting materials. This technology has now been commercialized globally and has contributed significantly towards the enhanced production of high quality planting material.

Reports on micropropagation of Aloe vera have been given by various researchers such as Sanchez et al., (1988), Natali et al., (1990) Meyer and Staden (1991), Roy and Sarkar (1991), Corneanu et al., (1994), Richwine et al., (1995), Abrie and Staden (2001), Chaudhuri and Mukandan (2001), Aggarwal and Barna (2004), Hosseini and Parsa (2007), Hashembadi and Kaviani (2008), Singh et al., (2009), Nayanakantha et al., (2010), Kumar et al., (2011), Biswas et al., (2013), Gantait et al., (2014) etc. 


\section{Plant material (Explant)}

The type of explants, size, position, age, physiological state and the manner in which it is cultured can affect the initiation of the cultures and further morphogenetic response (Murashige, 1974). Often there is an optimum size of explant suited to initiate cultures. Very small shoot tips or fragments do not survive well while it is difficult to decontaminate larger explants. The size of explant is also likely to influence the uptake of mineral salts irrespective of whether it is grown on liquid or solid medium (George and Sherrington, 1984).

Various plant parts like shoot tip or meristem, leaf segments, floral parts, aerial roots etc., have been successfully used for in vitro propagation.

Murashige (1974, 1978 and 1979) recognized four basic production stages of micropropagation achieved directly from proliferation of axillary bud, organogenesis, and somatic embryogenesis. This categorization of production stages has been used extensively. Stage I, II and III occur in vitro, while stage IV occurs in a hardening chamber.

Hirimburegama and Gamage (1995) introduced axillary and apical buds as explants for multiple shoot formation.

For micropropagation of Aloe vera various types of explants such as shoot tip, leaf tip, leaf segment, axillary branch, bud, stem were used successfully for multiple shoot production directly. Of these, shoot tips found to be the most suitable explants for micropropagation by majority of the researchers (Aggarwal and Barna, 2004; Hashemabadi and Kaviani, 2008; Bhandari et al., 2010; Kumar et al., 2011; Biswas et al., 2013).
Some of the researchers reported that Aloe vera micropropagation studies had been performed using mainly underground stems as explants (Roy and Sarkar, 1991; Kawai et al., 1993; Corneanu et al., 1994; Zhou et al., 1999). Such explants suffer from a relative high contamination level and phenolic substances.

There is no report on the successful micropropagation of Chinese aloe, partly because of the difficulties in establishing primary explants (Liao et al., 2004). In this approach young and strong underground stem were used as primary explants and successfully cultured propagation of Chinese aloe.

Kay et al., (2005) used two explants types, such as stem tips including apical meristem and leaf base from aseptic plant of Aloe vera. Growth and development of leaf base were not observed until three months; it turned into brown in colour and died within the culture period.

Oliveria and Crocomo (2009) used four hundred eighty apical buds explants , each 1 $\mathrm{cm}^{3}$, were isolated from young lateral shoots bearing six to nine leaves. Atleast 300 microplants were produced from a single apical bud of Aloe vera in a period of 4 months.

Nayanakantha et al., (2010) used lateral shoots (suckers) of Aloe vera (one month old). Explants were prepared by removing roots and brown coloured tissues and extending leaf portions to give an average size of $3-4 \mathrm{~cm}$.

On the basis of higher yield of leaf biomass Bhandari et al., (2010) collected shoot tip of 2.0-3.0 cm from offshoot-derived elite individual of the superior genotype of Aloe vera. New buds starts to appear from the axil 
of shoot tip of explants after 4 weeks of inoculation.

Das et al., (2010) concentrates on high frequency micropropagation of disease free quality plants of Aloe vera from shoot apical meristem. New buds were obtained from a single explant which indicates the efficiency of this protocol.

Kumar et al., (2011) used shoot tips as explant which starts to show signs of proliferation after two weeks of culturing. New buds starts to appear from the axil of leaves of shoot explants and buds develop into shoots by 4 weeks of culture.

Seeds and meristems were also used as explants for callus induction, and plant regeneration. Abrie and Staden (2001) found that by taking seeds as explant is possible to establish sterile culture.

The use of seeds for the establishment of primary cultures can prevent most of the decontamination problems that are often associated with explant establishment.

Micropropagation using stem and lateral shoot pieces of Aloe vera had already been proved successful (Meyer and Staden, 1991; Aggarwal and Barna, 2004). Khanam et al., (2014) used lateral shoots to develop a system for the mass propagation of Aloe vera through different combinations of plant growth regulators and found that it supports the data of many researchers.

Gupta et al., (2014) tested various explants such as nodal segments, apical and leave for understanding in vitro response in nutrient media.

Among the 3 explants, the apical bud explants gave the best results and were used for further experiments.

\section{Decontamination/ Explant disinfection}

Sterilization of explants is an essential requirement in order to improve the success of micropropagation. In the process of sterilization living materials should not lose their biological activity, but only bacterial or fungal contaminants should be eliminated. The commonly used sterilants are bleach, ethanol, sodium hypochlorite, mercuric chloride. The type of sterilant used, concentration and time depends on the nature of explant and species (Razdan, 1993).

The use of seeds for the establishment of primary cultures can prevent most of the decontamination problems that are often associated with explant establishment (Abrie and Staden, 2001). The seeds were scarified using sandpaper or a scalpel blade prior to treatment. Seeds were decontaminated in $70 \%$ ethanol for 2 minutes followed by a 10 minutes rinse in $1 \% \mathrm{NaOCl}$ solution. The seeds were then rinsed thoroughly in sterile distilled water.

After cutting young and strong underground stem into pieces with 1-2 buds, Liao et al., (2004) washed the explant under running tap water for 24 minutes. Stems with buds were surface disinfected with $70 \%$ (v/v) ethanol for 1 minute and $0.1 \%(\mathrm{w} / \mathrm{v}) \mathrm{HgCl}_{2}$ for 10 minutes followed by five rinses with sterile deionized water. The surface disinfected stems were cut into $1-2 \mathrm{~cm}$ segments each with buds.

Kay et al., (2005) washed leaf tips of Aloe vera with water thoroughly under tap. Then, leaves were removed and leafless tips were swapped with $70 \%$ ethanol. After that, they were clean with sterile water and dipped in 15\% Cocorex solution for 20 minutes. Finally dissected explants were rinsed with sterile distilled water and inoculated in culture media. 
Singh et al., (2009) kept axillary shoot segments and root tips in a chilled, sterile anti-oxidant solution $(200.0 \mathrm{mg} / \mathrm{l}$ of ascorbic acid, $50.0 \mathrm{mg} / \mathrm{l}$ of citric acid, and $25.0 \mathrm{mg} / \mathrm{l}$ of polyvinylpyrrolidone; PVP). These were washed carefully and sectioned into segments of 3.0-6.0 cm in length and $0.3-0.5 \mathrm{~cm}$ in thickness. These were pretreated with $0.1 \%$ aqueous solutions of bavistin (a systemic fungicide) and streptomycin (an antibiotic) for 15 minutes and surface sterilized with a $0.1 \%$ aqueous solution of mercuric chloride $\left(\mathrm{HgCl}_{2}\right)$ for 4-5 minutes. The surface-sterilized sections were washed several times with autoclaved water and kept in chilled sterile antioxidant solution for 5 minutes.

Shoot tip explants containing 1-2 buds were washed via tap water for 30 minutes followed by surface sterilization using $2 \% \quad(w / v)$ $\mathrm{NaOCl}$ for 30 minutes (Hashemabadi and Kaviani, 2008). The explants were thoroughly rinsed with sterile water. The surface disinfected explants were cut into $1 \mathrm{~cm}$ segments, each with buds. Again, explants were sterilized using $1 \%$ (w/v) $\mathrm{NaOCl}$ for 2 minutes followed by three rinses with sterile water.

Kumar et al., (2011) washed shoot tips thoroughly in running tap water for 15 minutes. After that they were again washed with liquid detergent and Tween 20 for 10 minutes with gentle shaking. After washing with detergent explants were again washed with running tap water to remove any traces of detergent for 15 minute and kept in $1 \% \mathrm{w} / \mathrm{v}$ solution of Bavistin for 1 hour. Subsequently, the explant was shifted to the $1 \%$ v/v solution of savlon for 1-2 minutes. Shoot tip were taken inside the laminar hood for further sterilization. Here 2-3 sterile water washings are given. After these washings, explants were taken out and dipped in $70 \%$ ethyl alcohol for 30 seconds and then dip into alcohol for 20 second, explants were surface sterilized with freshly prepared $0.1 \% \mathrm{w} / \mathrm{V}$ aqueous solution of mercuric chloride for 5 minutes. After mercuric chloride treatment, explants were thoroughly washed for 4-5 times with sterile water to remove any traces of mercuric chloride. Medium was autoclaved at $121^{\circ} \mathrm{C}$ for 20 minutes.

Sharifkhani et al., (2011) removed soil and dusts from roots explant, were cut carefully 1 $\mathrm{cm}$ below the transition zone. Leaves were cut from around the nodal region and exuded gel and the parts were washed for 30 minutes under running tap water. Different concentrations of sodium hypochlorite were prepared in $2.5 \%, 3.75 \%, 5 \%, 6.25 \%, 7.5 \%$ (commercial brand Clorox 10\%, 15\%, 20\%, $25 \%, 30 \%$ ) with distilled water and 5 drops of Tween 80 in one litre of solution. The explants were soaked in $70 \%$ ethanol for 30 seconds then were exposed to each concentration for a period of 20 minutes with hard and constant shaking approximately 250 rpm.

Biswas (2013) collected lateral shoots explants which was prepared by removing roots and brown colour tissues and extending leaf portions to give an average size of 3-4 $\mathrm{cm}$. They were washed thoroughly with running tap water for about 10 minutes till all soil and other foreign materials washed off. Sets of twenty explants were then washed with tap water containing a few drops of Tween 20 and rinsed in $70 \%$ ethanol for 30 seconds followed by initial soaking in sodium hypochlorite containing approximately $4 \%$ available chlorine for 10 minutes and then in freshly prepared mercuric chloride solution $(0.1 \%)$ for 10 minutes. Finally they were washed 3-4 times with sterile distilled water before culturing.

Gupta et al., (2014) collected leaves from healthy plants of Aloe vera washed thoroughly under running tap water followed 
by a dip in 5\% Teepol (liquid detergent) for 5 minutes. The leaves were washed clean of any traces of detergent prior to transfer to laminar flow cabinet. Further sterilization was done with $0.05-0.4 \% \mathrm{HgCl}_{2}$ for 5-15 minutes, followed by a quick dip in $70 \%$ ethanol for 1 minute and then washed thoroughly with sterile distilled $\mathrm{H}_{2} \mathrm{O}$ 3-4 times to remove all traces of chemicals. The leaves were placed over sterile blotting paper for soaking the excess water from the surface. With the help of a sterile blade, the leaves were then cut into rectangular sections of $5 \mathrm{~mm}$ by $5 \mathrm{~mm}$ with the midrib intact and placed on the medium with the dorsal side down.

\section{Culture media}

The success of plant tissue culture is greatly influenced by the nature of the culture medium used. Plant tissue culture media provides major and minor nutrient elements and carbohydrates. A wide variety of media have been reported. The choice depends on the plant species and the intended use of the culture. Nutritional requirements for optimal growth of a tissue may vary with species. Even tissue from different parts of a plant may have different requirement for satisfactory growth (Murashige and Skoog, 1962).

Murashige and Skoog (1962) medium characterized by high concentration minerals salts has been widely used for general plant tissue culture. No other factor has received as much attention as media, since the success in plant cell culture is largely determined by the quality of nutrient media (Vasil and Thorpe, 1994).

Ahmed et al., (2007) cultured the explants on MS nutrient medium supplemented with different concentration $(0.5,1.0,1.5,2.0,2.5$, $3.0 \mathrm{mg} / \mathrm{l})$ of $\mathrm{BA}$ and $\mathrm{KIN}$ alone or in combination of BA, KIN and NAA. The explants began to show the signs of shoot proliferation after two weeks of culturing. All explants gave aseptic cultures. Plants were free from both fungal as well as bacterial contamination.

Bhandari et al., (2010) inoculated the microshoots on MS basal medium (Murashige and Skoog, 1962) with different concentrations and combinations of BA and KIN (in combination of IBA $0.2 \mathrm{mg} / \mathrm{l}$ ) for shoot proliferation. Both BA and KIN were found to give the indications of shoot proliferation after 2 weeks of incubation. It was found that BA gave better shoot proliferation than KIN.

Explants produced multiple shoots on MS cultures containing $13.32 \mu \mathrm{M}$ BAP. The cut end of explants exhibited excessive leaching of phenolic substances, a cause of browning of the culture medium detrimental for cultures in vitro (Singh et al., 2009). The incorporation of antioxidants to the culture medium promoted growth and prevented browning of the culture and the nutrient medium.

Shoot bud induction was found best in MS containing $35.5 \mu \mathrm{M}$ BAP, $9.8 \mu \mathrm{M}$ IBA and $81.4 \mu \mathrm{M}$ adenine sulphate (Das et al., 2010).

Murashige and Skoog (1962) medium was the one most frequently used and occasionally different media such as N69, PRL-4-C, Knudson C, WPM, Gresshoff and Doy and $\mathrm{SH}$ were also used by different workers.

\section{Growth regulators}

Selection of appropriate combinations of plant growth regulators is the most important aspect in developing a successful protocol for tissue culture. For obtaining desired response in tissue culture, the role of growth regulators and their concentrations will have to be 
carefully chosen. The most important developments in the tissue culture of the plants were with the discovery of growth regulators, auxins, gibberellins, cytokinins, abscisins and other organic compounds like inositol and B-vitamins.

Growth and morphogenesis in vitro are regulated by the interaction and balance between the growth regulators supplied in the medium and the growth substances produced endogenously by the cultured cells. Apart from the direct effect on cellular mechanisms, many synthetic regulators may modify the level of endogenous growth substances (George and Sherrington, 1984).

Murashige (1974) used rapidly multiplied shoot tips and a satisfactory rate of increase in divisions was obtained by simply lowering the IAA level in the basal medium.

Some researchers have indicated that the presence of both auxin and cytokinin is necessary for shoot establishment and proliferation (Roy and Sarkar, 1991; Rout et al., 2001; Velcheva et al., 2005).

\section{Shoot initiation and multiplication}

Natali et al., (1990) were the first research group to report a method for direct multiple shoot initiation and proliferation from meristem tips using MS medium supplemented with $0.02 \quad \mathrm{mg} / \mathrm{l} \quad 2,4$ dichlorophenoxy acetic acid (2,4-D) plus 0.5 mg/l N6-benzyladenine (BA).

Meyer and Staden (1991) reported that indole-3-butyric acid (IBA) at $1 \mathrm{mg} / \mathrm{l}$ plays the exclusive role to induce multiple axillary buds to turn into shoots and spontaneous roots from decapitated shoot explants. More adventitious and axillary buds developed on nutrient media supplemented with IBA rather than with $\alpha$-napthalene acetic acid (NAA). In the presence of indole-3-acetic acid (IAA) in the nutrient medium only, axillary buds were developed.

Some Scientists reported that the presence of the plant growth regulators, particularly cytokinin in culture medium is the most important factors for shoot initiation and proliferation (Abrie and Staden, 2001; Chaudhuri and Mukandan, 2001; Aggarwal and Barna, 2004; Liao et al., 2004; Mamidala and Nanna, 2009; Hoque, 2010; Abadi and Hamidoghli, 2009). A range of cytokinins (BA, BAP, KIN and Zeatin) has been used for Aloe vera micropropagation (Velcheva et al., 2005; Araujo et al., 2002; Debiasi et al., 2007; Liao et al., 2004; Namli et al., 2010). Some researchers have shown that the presence of both of auxin and cytokinin is necessary for shoot proliferation (Roy and Sarkar, 1991; Rout et al., 2001; Velcheva et al., 2005).

The suitable ratio of cytokinin to auxin for the multiplication of the Aloe arborescence was determined as 10:1 by $\mathrm{Wu}(2000)$.

Liao et al., (2004) reported that the best medium for micropropagation of Aloe vera was that supplemented with $2 \mathrm{mg} / \mathrm{l} \mathrm{BA}+0.3$ mg/l NAA.

Baksha et al., (2005) cultured shoot tip explants on MS supplemented with various concentrations and combinations of BAP, NAA and BAP alone for induction of adventitious shoots. The best and rapid regeneration was observed on MS supplemented with $2 \mathrm{mg} / \mathrm{l} \mathrm{BAP}+0.5 \mathrm{mg} / \mathrm{l}$ NAA. This treatment yielded highest percentage of multiplication (75\%), 10 number of regenerated shoots per culture having shoot length of $4 \mathrm{~cm}$.

Ahmed et al., (2007) observed that multiplication of shoots was found best on 
MS medium in combination of BA $2.0 \mathrm{mg} / \mathrm{l}$, KIN $0.5 \mathrm{mg} / \mathrm{l}$ and NAA $0.2 \mathrm{mg} / \mathrm{l}$. and the emergence of shoots took place in 2 weeks and the percentage of shoot proliferation and the number of shoots per explant was $98.96 \%$ and 15.39 numbers.

Hashemabadi and Kaviani (2008) observed that shoot tip explants on medium with 0.5 $\mathrm{mg} / \mathrm{l} \mathrm{BA}+0.5 \mathrm{mg} / \mathrm{l} \mathrm{NAA}$ showed signs of proliferation after two weeks. Highest number of shoots per explant 9.67 was produced on medium containing $0.5 \mathrm{mg} / \mathrm{l} \mathrm{BA}+0.5 \mathrm{mg} / \mathrm{l}$ NAA. The least number of shoots per explant (nil) was shown in hormone-free medium.

Singh et al., (2009) reported that bud breaking occurred in cultures after 28-32 days leading to multiple shoot production. Maximum response was observed on semi-solid agar gelled MS medium with $13.32 \mu \mathrm{M}$ of BAP and additives. From each explants $10.3 \pm$ 0.675 shoots $(2.49 \pm 0.345 \mathrm{~cm}$ long $)$ were regenerated.

Nayanakantha et al., (2010) reported that the maximum number (16.0) of shoot bud per explant with a shoot length of $1.0 \pm 0.3$, was observed in the presence of $4.0 \mathrm{mg} / \mathrm{l} \mathrm{BAP}$ and $0.2 \mathrm{mg} / \mathrm{l} \mathrm{NAA}$ within four weeks of culture.

Bhandari et al., (2010) observed that new buds starts to appear from the axil of shoot tip of explants after 4 weeks of inoculation. Both BA and KIN were found to give the initiation of shoot proliferation after 2 weeks of incubation. BA $(1 \mathrm{mg} / \mathrm{l})$ containing medium showed $100 \%$ shoot proliferation with $3.3 \pm$ 1.1 numbers of shoot per explants while KIN $(1 \mathrm{mg} / \mathrm{l})$ containg medium showed $90 \%$ shoot proliferation with $3.1 \pm 1.1$ number of shoots.

Das et al., (2010) found the best shoot bud induction in MS containing 35.5 $\mu \mathrm{M}$ BAP, 9.8 $\mu \mathrm{M}$ IBA and $81.4 \mu \mathrm{M}$ adenine sulphate while the best shoot multiplication was found in medium containing $8.87 \mu \mathrm{M}$ BAP, $2.46 \mu \mathrm{M}$ IBA and $108.58 \mu \mathrm{M}$ adenine sulphate which produced $22.0 \pm 0.14$ numbers of shoot per explants with $4.20 \pm 0.03 \mathrm{~cm}$ shoot length.

Hashemabadi and Kaviani (2010) cultured shoot tip explants on medium with $0.5 \mathrm{mg} / \mathrm{l}$ $\mathrm{BA}+0.5 \mathrm{mg} / \mathrm{l} \mathrm{NAA}$ and it showed signs of proliferation after two weeks. The highest number of shoots per explants (3.15) was obtained on the medium containing $0.5 \mathrm{mg} / \mathrm{l}$ $\mathrm{BA}+0.5 \mathrm{mg} / \mathrm{l} \mathrm{NAA}$.

Jayakrishna et al., (2011) reported that shoot tip explants of Aloe vera L. showed best response $80 \%$ in MS mediun containing 2 $\mathrm{mg} / \mathrm{l} \mathrm{BAP}$.

Kumar et al., (2011) reported that explants started to show initiation of shoot proliferation after two weeks of culturing. In medium containing BA $(1 \mathrm{mg} / \mathrm{l})$, on an average each explant gave rise to 3.0-3.3 shoots and 100\% cultures showed shoot proliferation. On medium containing KIN (1 $\mathrm{mg} / \mathrm{l}$ ), only $90 \%$ cultures showed shoot proliferation. The explants which were cultured on medium without any phytohormone, failed to produce any new shoots.

Biswas et al., (2013) reported that after inoculation of explants, shoots started to proliferation after two weeks of culturing where shoot induction percentage was $100 \%$. After 8 weeks, the best proliferation of average number of shoot per explants was 7.8 for the medium containing of $2 \mathrm{mg} / \mathrm{l} \mathrm{BA}$ with $0.5 \mathrm{mg} / \mathrm{l} \mathrm{NAA}$.

Abdi et al., (2013) tested the response of the different Aloe vera explants on media containing different levels and combination of cytokinins and auxin. Shoot initiation was more pronounced in MS medium contain 0.2 $\mathrm{mg} / \mathrm{l} \mathrm{NAA}$ and $4 \mathrm{mg} / \mathrm{l} \mathrm{BA}$. Maximum number 
of shoots per explant 11.2 was achieved in MS medium with and $4 \mathrm{mg} / \mathrm{l} \mathrm{BA}$.

Zakia et al., (2013) studied the effect of various PGRs including cytokinin (BAP) and auxin (NAA) assessed for shoot proliferation of Aloe vera. Shoot multiplication was found best in MS medium supplemented by $0.5 \mathrm{mg} / \mathrm{l}$ BAP and $0.5 \mathrm{mg} / \mathrm{l}$ of NAA. After 7 weeks of inoculation, greatest number of shoots (11.18) and highest shoot length $(12.15 \mathrm{~cm})$ was achieved.

Daneshvar et al., (2013) studied the effect of cytokinins on shoot proliferation of Aloe vera. In media free of cytokinin, the explants produced mostly callus and/or a single shoot along with rhizogenesis. In this experiment, the shoot tip explants in MS media containing different concentrations of BAP $+\mathrm{KIN}+$ NAA showed greater effect than BAP + NAA on shoot proliferation.

Khanam et al., (2014) reported that a perfect combination of auxin and cytokinin is needed for optimum shoot induction. MS basal medium in combination with $4.0 \mathrm{mg} / \mathrm{l} \mathrm{BAP}$ and $0.2 \mathrm{mg} / \mathrm{l} \mathrm{NAA}$ was found to be the best on which explants began to show emergence of shoot buds within one week.

Within four weeks maximum shoots per explants on this combination was $14.3 \pm 0.33$ and length of plantlets was found $1.8 \pm 0.67$ $\mathrm{cm}$ and after 6 weeks number of maximum shoots per explants was $18.1 \pm 0.61$ and length of plantlets were found $2.5 \pm 0.39$.

Dwivedi et al., (2014) found that shoot proliferation occurred in presence of cytokinin. Cytokinin level produced a significant response upon the number of explants formed per plant and also showed influence on production of leaf numbers and rooting. Shoot multiplication was best on MS medium containing $1.5 \mathrm{mg} / \mathrm{l}$ BA. The percentage of shoot proliferation and number of shoots were 90 and 14 respectively.

Gupta et al., (2014) tried to develop an efficient protocol of in vitro culture to obtain maximum plantlets regeneration. The best and rapid in vitro formation of microshoots through the callus phase was observed on MS supplemented with $2 \mathrm{mg} / \mathrm{l} \mathrm{BAP}+0.5 \mathrm{mg} / \mathrm{l}$ NAA. Maximum shoot produced was $4.8 \pm$ 0.53 with average length of $3.5 \pm 0.35 \mathrm{~cm}$.

\section{In vitro rooting}

Abrie and Staden (2001) observed that rooting response was unpredictable and investigate the influence of the auxin IBA $(0.5 \mathrm{mg} / \mathrm{l})$, compared to the response on MS medium containing BA $(0.1 \mathrm{mg} / \mathrm{l})$. After four weeks, $64.2 \%$ of the plantlets had formed roots on the IBA containing medium, compared to only $21.4 \%$ on the BA containing medium. After eight weeks, this improved to $71.4 \%$ and $64.4 \%$ respectively. On both media, the roots appeared normal and turned yellow or brown at maturity.

Baksha et al., (2005) reported that root formation was induced in in vitro regenerated shoots by culturing them on half strength of MS supplemented with 0.5 to $1.5 \mathrm{mg} / \mathrm{l}$ of IBA or NAA or IAA. In the medium with $0.5 \mathrm{mg} / \mathrm{l}$ of NAA, roots began to emerge from the 10th day of culture and within a period of 23-28 days frequencies of root formation were $95 \%$. The highest number of roots per shoot was 4.8 \pm 0.53 with an average length of $3.5 \pm 0.35$ $\mathrm{cm}$. The roots that developed in the medium containing higher concentration (1.0-1.5 mg/l) of auxin, were poor in quality.

Ahmed et al., (2007) reported that proliferating shoots took maximum 7-8 weeks to attain the size suitable for rooting $(>2 \mathrm{~cm})$. The highest percentage of shoots that induced roots $(80.25 \%)$ was observed in MS medium 
supplemented with NAA $0.2 \mathrm{mg} / \mathrm{l}$, followed by IBA $0.2 \mathrm{mg} / \mathrm{l}$. Effect of IAA in rooting was very poor. The highest number of root per culture (6.71) was found in MS medium containing NAA $0.2 \mathrm{mg} / \mathrm{l}$.

Hashemabadi and Kaviani (2008) found that rooting percentage was improved in the presence of low concentrations of $\mathrm{BA}$ and NAA. They also revealed that there is a negative correlation between rooting and BA concentration in the medium. The shoots showed good rooting on MS medium supplemented with $0.5 \mathrm{mg} / \mathrm{l} \mathrm{BA}+0.5 \mathrm{mg} / \mathrm{l}$ $\mathrm{NAA}$ and $1 \mathrm{mg} / \mathrm{l} \mathrm{BA}+0.5 \mathrm{mg} / \mathrm{l} \mathrm{NAA}$. The largest number of roots was obtained on medium supplemented with $0 \mathrm{mg} / \mathrm{l} \mathrm{IBA}+1$ mg/l NAA (9.71) and the longest $(8.75 \mathrm{~cm})$ and thickest $(4.3 \mathrm{~cm})$ roots were achieved on medium supplemented with $1 \mathrm{mg} / \mathrm{l} \mathrm{IBA}+1$ mg/l NAA.

Singh et al., (2009) recorded, on hormonefree half-strength semi-solid MS salts with $200.0 \mathrm{mg} / \mathrm{l}$ of activated charcoal, $100 \%$ of the shoots rooted at $32 \pm 2{ }^{\circ} \mathrm{C}$. Root induction was observed after 10-12 days of inoculation. Cloned shoots also rooted under ex vitro conditions if treated with root-inducing hormone (IBA/NAA) for 5 minutes. Treatment of shoots with $2.473 \mathrm{mM}$ NAA for 5 minutes, more than $95 \%$ of the shoots was rooted on soilrite. Root initiation was observed after 13-15 days of auxin treatment. Higher concentrations (more than $2.473 \mathrm{mM}$ ) of root-inducing hormone (NAA) cause deterioration of shoot bases and no rooting was observed there. On lower concentrations of NAA (less than $2.473 \mathrm{mM}$ ), the percentage of rooting was less and root induction was also delayed.

Nayanakantha et al., (2010) suggest that external application of auxin is not necessary for root induction of Aloe vera and these results are consistent with the findings of
Agarwal and Barna (2004) and Roy and Sarkar (1991). Shoots in the initial regeneration media containing BAP alone or in combination with NAA did not produce roots. However, media containing activated charcoal irrespective of presence of citric acid induced roots after one month of culture. However, the roots initiated in these media were thin and delicate. Therefore, rooting potential in two other media; one devoid of growth hormones and other containing 0.2 mg/1 NAA was evaluated. Rooting occurred within two weeks in all rooting media. $100 \%$ rooting was observed in media containing 0.2 mg/1 NAA with $1.3 \pm 0.34$ numbers of roots and $4.1 \pm 0.55 \mathrm{~cm}$ root length, while $90 \%$ rooting was observed in media containing 0.5 $\mathrm{g} / 1$ activated charcoal irrespective of presence of citric acid and lacking hormones within two weeks of culture with $1.4 \pm 0.72$ numbers of root and root length was $3.1 \pm 0.52 \mathrm{~cm}$.

Bhandari et al., (2010) recorded that the rooting response was improved in hormone free medium. The shoots inoculated on hormone free and IBA supplemented medium showed rooting response within a week. After 15 days of inoculation, rooting was $100 \%$ in hormone free medium. The number of roots per shoot was $2.8 \pm 0.2$ on hormone free medium. In both the cases roots were without any branches and normal in appearance. Average number of roots per plant was found $2.2 \pm 1.2$ in medium containing hormones. Das et al., (2010) has obtained induction of roots in all the concentrations of Aloe gel without addition of sucrose and growth regulators. For induction of roots different concentrations of 2.45-9.8 $\mu \mathrm{M}$ IBA and 2.69- $10.64 \mu \mathrm{M}$ NAA were tried separately and obtained $80 \%$ root induction in $2.45 \mu \mathrm{M}$ IBA and $77 \%$ root induction in $2.69 \mu \mathrm{M}$ NAA. The highest percentage $(100 \%)$ of rooting with $10.90 \pm 0.17$ numbers of root and $3.02 \pm 0.11$ root length was obtained while using Aloe gel in rooting medium. 
Kumar et al., (2011) reported that the shoots inoculated on hormone free and IBA supplemented medium showed rooting response within a week of inoculation. However, the response was better in hormone free medium. After the 15 days of inoculation, rooting was $100 \%$ in hormone free medium. The number of roots per shoot was $2.8 \pm 0.5$ on hormone free medium. In case of hormone free medium, roots were more thick and elongated, while the roots on hormone supplemented medium were thin and less elongated and average number of roots per plant was $1.7 \pm 1.1$.

Biswas et al., (2013) observed that rooting percentage was improved in presence of low concentrations of IBA and NAA and do not support $100 \%$ rooting in Aloe vera in hormone free medium. No adventitious roots were initiated in auxin free media. Old leaves and shoots greater than $10 \mathrm{~cm}$ in size did not induce adventitious roots under any conditions. NAA $(0.5 \mathrm{mg} / \mathrm{l})$ was most effective for bringing about improvements in induction rate $(90 \%), 5.2$ number of adventitious roots per explants during six weeks of culture.

Dwivedi et al., (2014) reported that highest percentage of root induction (80\%) was observed in MS medium supplemented with $0.5 \mathrm{mg} / \mathrm{l}$ IBA and healthy rooting was observed. Healthy roots i.e more than 10 number of roots having root length of more than $6 \mathrm{~cm}$ was ob tained in the same medium after 8 weeks of culture.

Gupta et al., (2014) found auxins (NAA) as best for root induction. Root formation was induced in in vitro regenerated shoots by culturing them on half strength of MS supplemented with 0.5 to $1.5 \mathrm{mg} / \mathrm{l}$ of any of the three plant growth regulators IBA, NAA or IAA. Root formation was not observed when shoots were cultured on a medium lacking auxin. It was also reported that the highest root multiplication in Aloe vera was found in MS medium containing BA $1.0 \mathrm{mg} / \mathrm{l}$ and IBA $0.2 \mathrm{mg} / \mathrm{l} .90 \%$ of root formation took place and the maximum number of root $\&$ shoot produced was $4.8 \pm 0.53$ with average length of $3.5 \pm 0.35 \mathrm{~cm}$.

Khanam et al., (2014) reported that roots were observed after one week of culture and the medium with $2.0 \mathrm{mg} / \mathrm{l} \mathrm{IBA}$ and $1.0 \mathrm{mg} / \mathrm{l} \mathrm{NAA}$ in combination with MS basal mediun was found best for root proliferation. Within two weeks maximum roots per explants on this combination was $3.4 \pm 0.47$ and length of roots were found $3.9 \pm 0.62 \mathrm{~cm}$ and after 4 weeks number of maximum roots per explants was $6.7 \pm 0.31$ and length of roots were found $7.1 \pm 0.53$. The least number of root per explants was zero found in hormone free medium.

\section{Hardening medium}

One of the major obstacles in the application of tissue culture methods for plant propagation has been the difficulty in successful transfer of plantlets from the laboratory to the field (Wardle et al., 1983). The reasons for such a difficulty appear to be related to the dramatic change in the environmental conditions. The environment of the culture vessel is one of low light intensity, with very high humidity (generally $100 \%$ ) and poor root growth, while the greenhouse and/or field conditions are typified by very high light intensity, low humidity and micro-flora (Desjardins et al., 1987). Several workers have developed protocols to overcome some of these constraints. These reasons for such a difficulty appear to be related to the dramatic change in the environment conditions.

The micropropagated plantlets should be hardened before transferring them to open 
conditions. The medium for hardening should have good water holding capacity, drainage and aeration.

The plantlets obtained through micropropagation should have roots that are capable of supporting further growth and development. They are usually transplanted into compost and kept in partial shade at a high ambient humidity for several days.

A suitable environment is often created by covering the plantlets either with glass or clear polyethylene or by subjecting them into intermittent misting. Plants are hardened by gradually reducing the humidity and increasing the light.

The term media is sometimes used to describe the mixture of materials such as peat, perlite, vermiculite, rockwool, sand and soil used for transferring the plantlets from in vitro conditions. Compost which is commonly used for rooting conventional cuttings is suitable for transferring these plantlets, but there may be marked differences in root growth and plantlet survival with different media (Rodriguez et al., 1987).

Peat may prove to be too acidic substrate for some species and some kinds of vermiculite are too alkaline in nature. In order to maximize the survival of in vitro derived plants, it is a routine practice to acclimatize them under high levels of relative humidity.

Hardening and ex vitro establishment of micropropagated plants in Aloe vera was achieved with appreciable success by most of the investigators and high percentage of whole plant recovery was reported (Abrie and Staden, 2001; Liao et al., 2004; Ahmed et al., 2007; Hashemabadi and Kaviani, 2008; Singh et al., 2009; Nayanakantha et al., 2010; Das et al., 2010; Bhandari et al., 2010; Kumar et al., 2011; Biswas et al., 2013; Gupta et al., 2014).
Rooted plantlets were potted in a mixture of potting soil, vermiculite and sand (1:1:1) and acclimatized in a mist house (Liao et al., 2004). Young Chinese aloes were planted in the field very successfully $(93 \%)$.

Ahmed et al., (2007) recorded $82 \%$ of survivability in mixture of garden soil, compost and sand in a proportion of 2:1:1 where rapid shoot length was also observed. It was also revealed that regenerated plants were morphologically similar to the mother (control) plant.

Hashemabadi and Kaviani (2008) successfully acclimatized the plantlets in plastic pots containing a mixture of cocopeat and perlite (1:1) covered with transparent plastic. The result of acclimatization showed that $95 \%$ of plantlets survived to grow under greenhouse conditions and were morphologically similar to mother plants.

A mixture of light soil with good drainage is suitable for acclimatization of this plant. Researchers have proposed a mixture of soil and sand $(1: 1)$ or soil, sand and perlite or vermiculite (1:1:1) for hardening of Aloe vera (Natali et al., 1990; Hirimburegama and Gamage, 1995).

Singh et al., (2009) found ex vitro plants to be easier to harden than in vitro plants. When $e x$ vitro rooting of shoots and hardening of plantlets are achieved in the greenhouse in a single step, the protocol takes a shorter time for plantlet production and is several times cheaper (Arya, Shekhawat and Singh, 2003; Arya, Singh and Shekhawat, 2002).

Nayanakantha et al., (2010) were successfully obtained well developed rooted plantlets (4.5$5 \mathrm{~cm}$ long) after two months of culture and $100 \%$ of the explants were survived during and after the acclimatization in the pots in the plant house. 
Rooted plantlets of Aloe vera transplanted to plastic pots containing garden soil and Farmyard manure (1:1) for their hardening. Among the $90 \%$ survival plants, some plants showed the symptoms of leap tip necrosis during shade house condition (Bhandari et al., 2010).

Rooted plantlets were transferred from culture bottles to plastic cups in mixture of 1:1 ratio of soil: FYM for their hardening prior to their final transfer to the soil, showed good percentage of survival $(85 \%)$ in both polyhouse and shade house (Kumar et al., 2011). In shade house, plantlets showed $82 \%$ survival rate.

Gupta et al., (2014) carried out hardening of rooted plants in pots containing 1:2 (v/v) mixture of sterile sand and soil in the greenhouse at $25 \pm 2^{\circ} \mathrm{C}$ under 2000 lux light intensity provided by white fluorescent lamps for 16 hours photoperiod. During the first week of hardening period, regenerated plants were covered by perforated polythene sheets for maintaining high humidity and irrigated with sterile distilled water, followed by irrigation with tap water in the second week. After an additional 2-3 weeks of incubation hardened plants were transferred to the field. Plants which were transferred directly to the field did not survive. The plantlets with welldeveloped roots were transferred to polythene bags and the acclimatized plants were finally transferred to soil with $70 \%$ survival rate.

From the above cited information it can be concluded that the technique of micropropagation of Aloe vera is used for rapid multiplication of plants, for genetic improvement, for obtaining disease-free clones and for preserving valuable germplasm. Compare to conventional propagation, micropropagation has the advantage of allowing rapid production in limited time and space which provides sufficient numbers of plantlets from a single stock plant. To overcome the slow propagation rate of Aloe vera, micropropagation will be a very useful technique for mass multiplication of Aloe vera.

\section{Abbreviations}

$\mathrm{AdSO}_{4}$ (Adenine sulphate), BAP (Benzyl amino purine), IBA (Indole butyric acid), NAA (Napthalene acetic acid)

\section{References}

Abdi, G.; Hedayat, M. and Modarresi, M. (2013). In vitro micropropagation of Aloe vera - Impacts of plant growth regulators, media and type of explants. J. Biol. Environ. Sci. 7(19): 19-24.

Abrie, A. and Staden, J.V. (2001). Micropropagation of endangered Aloe polyphylla. Pl. Growth Reg. 33(1): 1923.

Aggarwal, D. and Barna, K.S. (2004). Tissue culture propagation of elite plant of Aloe vera Linn. J. Plant Biochem. Biotechnol. 13: 77-79.

Ahmed, S.; Kabir, A.H.; Ahmed, M.B.; Razvy, M.A. and Ganesan, S. (2007). Development of rapid micropropagation method of Aloe vera L. Sjemenarstvo 24(2): 121- 128.

Araujo, P.S.; Silva, J.M.O.; Neckel, C.; Ianssen, C.; Oltramaria, A.C.; Passos, R.; Tiepo, E.; Bach, D.B. and Maraschin, M. (2002). Micropropaga cao de babosa (Aloe vera L.). Biotecnologia de plantas Medicinais. Biotecnologia ciencia e Desenvolvimento 25: 54-57.

Arya, V.; Shekhawat, N.S. and Singh, R.P. (2003). Micropropagation of Leptadenia reticulate- A medicinal plant. In vitro Cell Dev. Biol. Pl. 39: 180-185. 
Arya, V.; Singh, R.P. and Shekhawat, N.S. (2002). A micropropagation protocol for mass multiplication and off-site conservation of Celastrus paniculatus A vulnerable medicinal plant of India. $J$. Sustain. Forest. 14(1): 107-120.

Baksha, R.; Jahan, M.A.; Khatun, R. and Munshi, J.L. (2005). Micropropagation of Aloe barbadensis Mill. through in vitro culture of shoot tip explants. Plant Tissue Culture Biotechnology, pp. 121126.

Bhandari, A.K.; Negi, J.S.; Bisht, V.K. and Bharti, M.K. (2010). In vitro propagation of Aloe vera - A Plant with Medicinal Properties. Nat. Sci. 8(8): 174-176.

Biswas, G.C.; Miah, M.; Sohel, H.M.; Hossain, A.K.M.; Shakil, S.K. and Howlader, M.S. (2013). Micro propagation of Aloe indica L. through shoot tip culture. J. Agri. Vety. Sci. 5: 30-35.

Carlson, P.S.; Smith, H.H. and Daring, R.D. (1972). Parasexual interspecific plant hybridization, USA. Proc. Nat. Acad. Sci. 69: 2292-2294.

Chaudhuri, S. and Mukundan, U. (2001). Aloe Vera L. - Micropropagation and Characterization of its gel. Phytomorphol. 51(2): 155-157.

Corneanu, M.; Corneanu, G.; Vekas, M. and Minea, R. (1994). In vitro organogenesis of Aloe arborescens (Liliaceae). Revue Roumaine de Biologie 39: 45-52.

Daneshvar, H.; Moallemi, N. and Zadeh, N.A. (2013). The effect of different media on shoot proliferation from the shoot tip of Aloe vera L. J. Nat. Pharm. Prod. 8(2): 93-97.

Das, A.; Mukherjee, P.; Ghorai, A. and Jha, T.B. (2010). Comparative karyomorphological analyses of in vitro and in vivo grown plants of Aloe vera $\mathrm{L}$. Burm. F. Nucleus 53: 89-94.
Debiasi, C.; Silva, C.G. and Pescador, R. (2007). Micropropagation of Aloe vera L. Rev. Bras. Pl. Me. 9: 36-43.

Desjardins, Y.A.; Goselin and Yellow, S. (1987). Acclimatization of in vitro straw berry plantlets in $\mathrm{CO}_{2}$ enriched environment and supplementary lighting. J. Amer. Soc. Hort. Sci. 112: 846-852.

Dwivedi, N.K.; Indiradevi, A.; Asha, K.I.; Nair, R.A. and Suma, A. (2014). A protocol for micropropagation of Aloe vera L. (Indian Aloe)- a miracle plant. Res. Biotechnol. 5(1): 01-05.

Feng, F.; Li, H.B.; Lu, Q.F. and Xie, J.Y. (2000). Tissue culture of Aloe spp. J. Southwest Agric. Univ. 22: 157-159.

Gantait, S.; Sinniah, U.R. and Das, P.R. (2014). Aloe vera: a review update on advancement of in vitro culture. Acta Agriculturae Scandinavica, Section B. Soil Plant Sci. 64(1): 1-12.

Gautheret, R.T. (1939). Sur la possabilite de reliser la culture idefinie des tissue de tubercules de carotte, C.R., Paris. Acad Sci. 208: 118-120.

George, E.F. and Sherrington, P.D. (1984). Plant propagation by tissue culture, Hand book of directory of commercial laboratories, Exegetics Ltd. Baningstoke, UK, pp. 67-85.

Gupta, S.; Sahu, P.K.; Sen, D.L. and Pandey, P. (2014). In vitro Propagation of Aloe vera (L.) Burm. f. British Biotechnol. J. 4(7): 806-816.

Haberlandt, G. (1902). Culturevessuche mit isoleerten pflanzenzellen, sitzungsber, math, naturwiss K1, Kais. Akad, Wiss. III: 69-92.

Hashemabadi, D. and Kaviani, B. (2008). Rapid micro-propagation of Aloe vera L. via shoot multiplication. Afr. $J$. Biotech. 7(12): 1899-1902.

Hirimburegama, K. and Gamage, N. (1995). In vitro multiplication of Aloe vera 
meristem tips for mass propagation. Hort. Sci. 27: 15-8.

Hoque, M.E. (2010). In vitro tuberization in potato (Solanum tuberosum L.). Plant Omics J. 3(1): 7-11.

$\mathrm{Hu}, \mathrm{C} . Y$. and Wang, P.T. (1983). Meristem, shoot tip and bud cultures. In: Hand book of plant cell culture, vol. 1 techniques for propagation and breeding (Evans, D.A., Sharp, W.R., Ammirato, P.V. and Yamada, Y. eds.), MacMillan Publishing company, New York, pp. 177-227.

Jayakrishna, C.; Karthik, C.; Barathi, S.; Kamalanathan, D. and ArulSelvi, I.P. (2011). In vitro propagation of Aloe barbadensis Miller, a miracle herb. Res. Plant Biol. 1(5): 22-26.

Kawai, K.; Beppu, H.; Koike, T.; Fujita, K. and Maruouchi, T. (1993). Tissue culture of Aloe arborescens Mill. Phytother Res. 7: 5-10.

Kay, T.M.; Thida, M.; Myo, H. and Khin, M.S. (2005). Meristem Culture Gf Aloe vera L. J. Myan Acad. Arts Sc. 3: Nb.f (ii) Botany.

Khanam, N.; Khanam, N. and Sarma, G.K. (2014). Rapid in vitro propagation of Aloe vera L. with some growth regulators using lateral shoots as explants. World J. Pharm. Pharmaceu. Sci. 3(3): 2278-4357.

Kumar, M.; Singh, S. and Singh, S. (2011). In vitro morphogenesis of a medicinal plant-Aloe Vera L. Asian J. Pl. Sci. Res. 1(1): 31-40.

Liao, Z.; Chen, M.; Tan, F.; Sun, X. and Tang, K. (2004). Micropropagation of endangered Chinese aloe. Pl. Cell Tiss. Org. Cult. 76: 83-86.

Litz, R.E. (1984). In vitro somatic embryogenesis from nucellular callus of monoembryogenic Magnifera indica L. Hort. Sci. 19: 715-717.

Litz, R.E. (1985). Somatic embryogenesis in tropical trees. In: Tissue culture in
Forestry and Agriculture. Henke, R.R.; Hughes, K.W.; Constantin, M.J. and Hollaender, A. (eds.). Plenum Press, New York, pp. 179-194.

Mamidala, P. and Nanna, R.S. (2009). Efficient in vitro plant regeneration, flowering and fruiting of dwarf Tomato cv. Micro-Msk. Plant Omics J. 2(3): 98102.

Meyer, H.J. and Staden, J.V. (1991). Rapid in vitro propagation of Aloe barbadensis Mill. Pl. Cell Tiss. Org. Cult., pp. 167171.

Morel, G.M. (1960). Producing virus free Cymbidium. Amer. Orch. Soc. Bull. 29: 495-497.

Morel, G.M. and Martin, C. (1952). Guerism de dahlia attaints d'une Maladie a virus, C.R., Paris. Acad. Sci. 235: 1324-1325.

Murashige, T. (1974). Plant propagation through tissue culture. Ann. Rev. Pl. Physiol. 25: 136-166.

Murashige, T. (1978). Principles of rapid propagation, In: Propagation of higher plants through tissue culture a bridge between research and application (Huges, K.; Henke, R. and Constantin, M. eds.) technology Information Centre, USDE Oak, Ridge, pp. 14-24.

Murashige, T. and Skoog, F. (1962). A revised medium for rapid growth and bioassays with tobacco cultures. Physiol. Planarum 15: 473-497.

Murashige, T.; Bitter, W.P.; Rangan, T.S.; Nauer, E.M.; Roistacher, C.N. and Holliday, P.P. (1972). A technique of shoot apex grafting and its utilization towards recovering virus free citrus clones. Hort. Sci. 7: 118-119.

Namli, S.; Akbas, F.; Isikalan, C.; Tilkat, E.A. and Basaran, D. (2010). The effect of different plant hormones (PGRs) on multiple shoots of Hypericum retusum Aucher. Plant Omics J. 3(1): 12-17.

Natali, L.; Sanchez, I.C. and Cavallini, A. (1990). In vitro culture of Aloe 
barbadensis Mill. Micropropagation from vegetative meristems. $\mathrm{Pl}$. Cell Tiss. Org. Cult. 20: 71-74.

Navarro, C.; Roistacher, C.N. and Murashige, T. (1975). Improvement of shoot tip grafting in vitro for virus free citrus. J. Amer. Soc. Hort. Sci. 100: 471-479.

Nayankantha, N.M.C.; Singh, B.R. and Kumar, A. (2010). Improved culture medium for micropropagation of Aloe vera L. Trop. Agri. Res. Ext. 13(4): 8793.

Oliveira, E.T.; de Crocomo, O.J.; Farinha, T.B. and Gallo, L.A. (2009). Largescale micropropagation of Aloe vera. Hort. Sci. 44: 1675-1678.

Razdan, M.K. (1993). An introduction to plant tissue culture, Oxford and IBH Publishing Company Pvt. Ltd., New Delhi, pp. 32-36.

Reinert, R.A. and Mohr, H.C. (1967). Propagation of cattleya by tissue culture of lateral bud meristems. Amer. Soc. Hort. Sci. 91: 664-671.

Richwine, A.M.; Tipton, J.L. and Thompson, A. (1995). Establishment of Aloe, Gasteria, and Haworthia shoot cultures from inflorescence explants. Hort. Sci. 30(7): 1443-1444.

Rodriguez, GA.; Martin, J.R.L. and Enrique, M.J.R. (1987). In vitro propagation of Canary island banana (M. accuminata Colla AAA var. Cavendis), studies of factors affecting culture, obtention, preservation and conformity of plants. Acta Hort. 212: 577-583

Rout, G.R.; Reddy, G.M. and Das, P. (2001). Study on in vitro clonal propagation of Paulownia tomentosa Steud. and evaluation of genetic fidelity through RAPD Marker. Silvae Genet. 50: 208212.

Roy, S.C. and Sarkar, A. (1991). In vitro regeneration and micro propagation of
Aloe vera. Scientia Hort. 47(1-2): 107114.

Sanchez, I.C.; Natali, L. and Cavallini, A. (1988). In vitro culture of Aloe barbadensis Mill. Morphogenetic ability and nuclear DNA content. Plant Sci. 55: 53-59.

Schleiden, M.J. (1838). Deitrage Zur phytogenesis. Muller Anat Wiss 11: 137-176.

Schwann, T. (1839). Mikroskopische untersuch un gen uber die uberinstimmung in der struktur and dem wach stume der tiere and pfanzen (Ostwalds Kallsiker de exakten Wissenschaften, No. 176 EngelmannLeipzig, p. 910.

Sharifkhani, A.; Saud, H. and Aziz, M. (2011). An alternative safer sterilization method for explants of Aloe vera barbadensis Mill. $2^{\text {nd }}$ International Conference on Chemical Engineering and Applications vol. 23.

Sharp, W.R.; Evans, D.A.; Ammirato, P.V. and Yamada, Y. (1984). Hand book of plant cell culture. In: Crop Species, Vol. 2, Macmillan Publishing Co., New York.

Singh, M.; Rathore, M.S.; Panwar, D.; Rathore, J.S. Dagla, H.R. and Shekhawat, N.S. (2009). Micropropagation of selected genotype of Aloe vera L. - an ancient plant for modern industry. J. Sustain. Forest. 28: 935-950.

Skoog, F. and Miller, C.C. (1957). Chemical regulation of growth and organ formation in plant tissue cultured cultured in vitro. Symp. Soc. Exp. Biol. 11: 118-131.

Steward, F.C.; Mapes, M.O. and Mear, S.K. (1958). Growth and organized development of cultured cell. II. Organization in cultures grown from freely suspended cells. Amer J. Bot. 48: 705-708. 
Styler, D.T. and Chin, C.K. (1983). Meristem and shoot tip culture for propagation, pathogen elimination and germplasm preservation. Hort. Rev. 5: 221-227.

Velcheva, M.; Faltin, Z.; Vardi, A.; Eshdat, Y. and Perl, A. (2005). Regeneration of Aloe arborescens via somatic organogenesis from young inflorescences. Pl. Cell Tiss. Org. Cult. 83: 293-304.

Wardle, K.; Dobbs, K.B. and Short, K.C. (1983). In vitro acclimatization of aseptically cultured plants to humidity. J. Amer. Soc. Hort. Sci. 108: 386-389.

Went, F. and Thimann, K.V. (1937). Phytohormones, Macmillan, Inc, New York.

White, P.R. (1934). Potentially unlimited growth of excised tomato root tips in a liquid medium. Plant Physiol. 9: 585600.

White, P.R. (1939). Potentially unlimited growth of excised tomato root tips in a liquid medium. Amer. J. Bot. 26: 59-64.

Wu, H.Z. (2000). Tissue culture of Aloe aborescens Miller. Acta Hort. Sin. 27: 151-152.

Zakia, S.; Zahid, N.Y.; Yaseen, M.; Abbasi, N.A.; Hafiz, A.A. and Mahmood, N. (2013). Standardization of micropropgation techniques for Aloe vera: A pharmaceutically important plant. Pak. J. Pharm. Sci. 26(6): 10831087.

Zhou, G.; Ding, H.; Shi, W. and Cheng, L. (1999). Fast asexual propagation of Aloe vera L. Acta Hort. 26: 410-411.

\section{How to cite this article:}

Jugabrata Das, Sunil Bora, Manosh Das and Purnima Pathak. 2018. A Review on in vitro Culture of Aloe vera, Type of Explants and Impact of Growing Media \& Growth Regulators. Int.J.Curr.Microbiol.App.Sci. 7(06): 3473-3489. doi: https://doi.org/10.20546/ijcmas.2018.706.407 